Egyptian Journal of Aquatic Biology \& Fisheries

Zoology Department, Faculty of Science,

Ain Shams University, Cairo, Egypt.

ISSN $1110-6131$

Vol. 24(7): 995 - 1003 (2020)

www.ejabf.journals.ekb.eg

\title{
Barium Chloride impairs physiology and brain glutamate in Cirrhinus mrigala during a short period of interaction
}

Jagadeep Chandra S. ${ }^{1}$, Vishwaprakash Mahadimane ${ }^{2}$, Asma Saqib ${ }^{3}$, Sandya Sukumaran ${ }^{4}$, Sharath Chandra SP. ${ }^{5, *}$

${ }^{1}$ Department of Microbiology, School of Life sciences, JSS academy of Higher Education and Research, Mysuru, India

${ }^{2}$ Department of studies in Bioscience, Hemagangothri, University of Mysuru, Mysuru, India

${ }^{3}$ Department of Biochemistry, Maharani`s Science College for Women, Bengaluru,India

${ }^{4}$ Department of Inorganic and Physical Chemistry, Indian Institute of Science, Bangalore, Karnataka, India.

${ }^{5}$ Department of Biochemistry, Government Science College, Hassan, Karnataka, India

*Corresponding Author: sharathchandrasp@gmail.com

\section{ARTICLE INFO}

\section{Article History:}

Received: July 16, 2020

Accepted: Dec. 26, 2020

Online: Dec. 30, 2020

Keywords:

Barium

Biochemical

Cirrhinus mrigala

Glutamate

oxidative stress

\section{ABSTRACT}

The present study was performed to establish the toxicological impact of barium chloride $\left(\mathrm{BaCl}_{2}\right)$ on freshwater fish Cirrhinus mrigala. In this direction we have investigated the ecological impact of $\mathrm{BaCl}_{2}$ on $C$ mrigala, a freshwater fish widely consumed. Biochemical, neurochemical, and physiological variations were carried out in the present study and $\mathrm{LC}_{50}$ of $\mathrm{BaCl}_{2}$ was found to be $12 \mathrm{ppm}$, observed for $24 \mathrm{hrs}$. Further $1 / 10^{\text {th }}$ of the $\mathrm{LC}_{50}$ concentration of $\mathrm{BaCl}_{2}(1.2 \mathrm{ppm})$ was selected for acute investigation for $96 \mathrm{hrs}$. The results exhibited an increase in serum lactate dehydrogenase (LDH), aspartate transaminase (AST), and alanine transaminase (ALT) levels compared to control groups. Studies revealed alterations in oxidative stress markers with a notable lowering in the serum superoxide dismutase (SOD), and catalase (CAT) levels, and an increase in malondialdehyde (MDA). The studies reported an elevation in brain glutamate concentrations indicating brain tissue damage. The study highlights the potential toxicological impact of $\mathrm{BaCl}_{2}$ on freshwater fish.

\section{INTRODUCTION}

The presence of xenobiotics and chemicals in the ecosystem due to their multipurpose applications and their let-outs lead to contamination of diverse ecosystems (Rashmi et al., 2019; Shyamala et al., 2020). Most of these chemicals, in the form of heavy metals and their derivatives, are not degradable and have the potential to bind to endogenous molecules as they enter the biological system, and hence, may lead to unfavorable toxic effects (Amdur et al., 1991). The presence of these metals in the living system can lead to unwanted changes in a cell that may be cascaded to the tissue or the organ (Bernet et al., 1991). Thus, a scenario of these xenobiotics to accumulate in fish 
and impair the food chain is created. Human beings, who consume fish products as food source, are also part of the food chain, thus generating a cause of concern in the public health (Di Giulio \& Hinton, 2008). The influence of chemicals and their derivatives in the tissues of aquatic animals, like fish, depends on several parameters like the immediacy of the pollutants to animals, metabolic activity and membrane permeability, and climate (Chen \& Folt, 2000).

Barium has been reported to cause toxicity due to the high dose exposure (Soudani et al., 2011), in addition, soluble salts of barium have been proved to be harmful to animals and plants (Purdey et al., 2004). Barium contamination could be related to firework, paper, textile, and other industries. Deleterious effects may occur due to the absorption of soluble barium compounds such as; nitrates and chlorides which are toxic to humans (Ananda et al., 2013). Following human ingestion, barium is reported to be toxic and extensively distributed in the heart, skeletal muscle, kidney, blood, and liver (Mc Cauley \& Washington, 1993). Thus we used freshwater fish Cirrhinus mrigala consumed extensively to assess the acute toxicity of barium chloride.

$\mathrm{LC}_{50}$ indicates the degree of resistance of a living system to xenobiotics (Reda $\boldsymbol{e t}$ al., 2010). Physiological alterations in fish exposed to these xenobiotics give the precise level of damage. Toxicity stress causes oxidative damage by the generation of free radicals (ROS) with the exhaustion of natural antioxidants. Measurement of oxidative stress markers, such as; superoxide dismutase, catalase, and, lipid peroxidation, indicates the physiological variations due to toxicity. Changes in neurotransmitter glutamate content were assessed, because neurons are vulnerable to free radicals, resulting in modification of glutamate levels, and thus, resulting in neurodegenerative disorder (Li et al., 2010). In this direction, we evaluated the physiological and neurochemical (glutamate) disturbances caused by barium chloride in freshwater fish $C$ mrigala in a short period exposure of $96 \mathrm{hrs}$.

\section{MATERIALS AND METHODS}

\section{Animals and Treatments}

Freshwater carp, $C$ mrigala $(6.6 \pm 0.8 \mathrm{~cm}$ of body length and $5.6 \pm 1.5 \mathrm{~g}$ of weight) were obtained from a fish farm. Water quality was noted to be $30.8 \pm 2.3 \mathrm{CaCo}_{3} \mathrm{mg} / \mathrm{L}$ of hardness and $\mathrm{pH}$ of $7.2 \pm 0.5$, at a temperature of $23 \pm 1^{\circ} \mathrm{C}$. For experiments, fishes were distributed into three groups which were raised in $100 \mathrm{~L}$ aquarium with continuous aeration.

\section{Barium chloride $\left(\mathrm{BaCl}_{2}\right)$ sample preparation}

$12 \mathrm{~g} / \mathrm{L}$ of $\mathrm{BaCl}_{2}$ solution was prepared in double-distilled water. The groups of fishes were treated with $\mathrm{BaCl}_{2}$ for short duration of $96 \mathrm{hrs}$ (4 days). The dosage of sample $1.2 \mathrm{mg} / \mathrm{L}$ was based on $1 / 10^{\text {th }}$ of $\mathrm{LC}_{50}$ concentration $(12 \mathrm{mg} / \mathrm{L})$. Water was changed daily and a freshly prepared solution of $\mathrm{BaCl}_{2}$ was added. The control group of 50 fishes was housed with comparable conditions to the treated group. Feeding was inhibited $24 \mathrm{hrs}$ before sacrifice to provide postprandial variations. Control and treated fishes $(1.2 \mathrm{mg} / \mathrm{L})$ were taken for further investigation. Zero mortality was observed during the entire $96 \mathrm{hrs}$ of exposure to $\mathrm{BaCl}_{2}$.

\section{Sample collection}

The cardiac puncture was made to draw the fishes blood. Samples, for physiological investigation, were transferred to EDTA vials following centrifugation at 
$9392 \mathrm{~g}$ at $4^{\circ} \mathrm{C}$ for $20 \mathrm{~min}$. The brain tissue, for analysis of glutamate, was dissected and cryopreserved. During analysis the brain tissue was homogenized with 8 volumes of cold Tris buffer saline $(10 \mathrm{mM}$ Tris- $\mathrm{HCl}, 10 \mathrm{mM}$ sucrose, $0.7 \% \mathrm{NaCl}, 0.1 \mathrm{mM}$ EDTA of $\mathrm{pH}$ 7.2) at $4^{\circ} \mathrm{C}$. The mixture was centrifuged at $3000 \mathrm{rpm}$ at $4^{\circ} \mathrm{C}$ for $12 \mathrm{~min}$, and the supernatant was taken for experiment.

\section{Physiological parameter analysis}

Blood glucose level was measured by preparing a reaction mixture of $0.1 \mathrm{ml}$ of plasma, $4 \mathrm{ml}$ of o-toluidine (Cooper, 1970), and mixed finally incubated for $10 \mathrm{~min}$ on a boiling water bath. The samples were cooled and the absorbance was measured at $630 \mathrm{~nm}$ in a UV spectrophotometer. The glucose content was expressed as $\mathrm{mg} / \mathrm{dL}$. Plasma protein levels were assessed by the method of Lowry et al. (1951). A100 $\mu$ l of plasma, $900 \mu 1$ of double distilled water and, Lowry reagent $4 \mathrm{ml}$ was mixed well and incubated for $10 \mathrm{~min}$ at room temperature. A $0.5 \mathrm{ml}$ of $\mathrm{FC}$ reagent was added to this mixture and incubated for $20 \mathrm{~min}$ at room temperature. The sample was then read at $720 \mathrm{~nm}$ and expressed in $\mu \mathrm{g} / \mathrm{ml}$.

\section{Serum transaminases analysis}

Serum L aspartate aminotransferase and L-alanine aminotransferase activities were investigated at $37^{\circ} \mathrm{C}$ following a colorimetric protocol of Reitman and Franckel (1951), and enzyme activity was measured as IU/L. Lactate dehydrogenase was evaluated by the procedure formulated by Anon (1984) and was expressed as IU/L.

\section{Oxidative stress markers and glutamate analysis}

Superoxide dismutase (SOD) was assessed (Das et al., 2000) through the inhibition of superoxide led nitrite generation from hydroxylamine hydrochloride. The absorbance was calculated at $540 \mathrm{~nm}$ and expressed as $\mathrm{U} / \mathrm{mg}$ of protein. Catalase activity was analyzed depending on the generation of stable hydrogen peroxide with ammonium molybdate, read at $405 \mathrm{~nm}$ and expressed as U/mg (Goth, 1991). Lipid peroxidation was measured with malondialdehyde (MDA) as standard (Buege \& Aust, 1978). The reaction of the mixture of sample and TCA-TBA $\mathrm{HCl}$ reagent was boiled for $10 \mathrm{~min}$, cooled, and then centrifuged at $10000 \mathrm{~g}$. The supernatant was used for quantification at $535 \mathrm{~nm}$ and expressed as nmol/mg. Glutamate levels were identified by multiple developments of paper chromatography (Raju et al., 2004). The supernatant was evaporated at $70^{\circ} \mathrm{C}$ and mixed with $100 \mathrm{ml}$ double distilled water. The sample, with 2 $\mathrm{mM}$ glutamate standard solution, was spotted on Whatman no.1 chromatography paper. Then, it was allowed to develop on the mobile phase (Butanol: acetic acid: water 12:3:5 $\mathrm{v} / \mathrm{v})$. The chromatogram developed again, the papers were dried and sprayed with ninhydrin and incubated at $100^{\circ} \mathrm{C}$ for $4 \mathrm{~min}$. The bands which reveal glutamate corresponding to the standard was cut and eluted in $75 \%$ ethanol with $0.005 \% \mathrm{CuSO}_{4}$. The absorbance was read against the blank at $515 \mathrm{~nm}$ in a spectrophotometer. The concentration was expressed as $\mu \mathrm{mol} / \mathrm{g}$ of glutamate.

\section{Statistical analysis}

The experimental results were statistically evaluated and represented as Mean $\pm \mathrm{SE}$. For all experiments, the degree of statistical significance was set for $\mathrm{P}<0.05$. The significance was determined by Student`s $t$-test using MS-Excel. 


\section{RESULTS}

This study investigated the impact of $\mathrm{BaCl}_{2}$ exposure on the physiological changes and glutamate contents in freshwater carp C. mrigala, by examining the physiological variables, oxidative stress and glutamate levels. The fish were distributed as treated with (1.2ppm of $\mathrm{BaCl}_{2}$ ), while control groups were set for comparison, and all were under supervision for 24, 48, 72, and $96 \mathrm{hrs}$. The blood assessment of $\mathrm{BaCl}_{2}$, treated with $C$. mrigala, reported a remarkable rise in glucose levels (Table 1) throughout the 4 days of the experiment, but, a major difference of $4.88 \pm 0.22 / 27.63 \pm 1.25$ was observed on the $4^{\text {th }}$ day $(96 \mathrm{hrs})$. The decline in plasma protein level (table 1) was significantly $(P<0.05)$ found in exposed groups $\left(1.2 \mathrm{ppm}\right.$ of $\left.\mathrm{BaCl}_{2}\right)$ on the $4^{\text {th }}$ day $(15.40 \pm 1.61 / 9.77 \pm 0.56)$ in comparison to the control groups. There was a distinct elevation in serum AST and ALT levels in exposed group, in all four days, compared to the control groups. Table 1 suggests the elevated activity of $\mathrm{LDH}$ in the treatment of $C$ mrigala fish with $\mathrm{BaCl}_{2}(1.2$ ppm). Figure 1 reports the rise in brain glutamate concentration in treated fish $(12.07 \pm 0.13)$ in comparison with the control group $(10.3 \pm 0.22)$ on the $4^{\text {th }}$ day.

Results in table 2 reveal a decline in SOD and CAT variables in the treated fish. The LPO evaluation in $C$ mrigala exposed to $1.2 \mathrm{ppm}$ of $\mathrm{BaCl}_{2}$, propose that liver may be the affected organ, as there is notable amplification in MDA levels.

Table 1: Changes in the physiological parameters of $C$ mrigala exposed to $\mathrm{BaCl}_{2}(1.2 \mathrm{ppm})$

\begin{tabular}{|c|c|c|c|c|c|c|c|c|}
\hline \multirow{3}{*}{$\begin{array}{c}\text { Biochemical } \\
\text { variables }\end{array}$} & \multicolumn{8}{|c|}{ Exposure duration (in h) $1.2 \mathrm{ppm}$} \\
\hline & \multicolumn{2}{|c|}{24} & \multicolumn{2}{|c|}{48} & \multicolumn{2}{|c|}{72} & \multicolumn{2}{|c|}{96} \\
\hline & $\mathrm{C}$ & E & $\mathrm{C}$ & $\mathrm{E}$ & $\mathrm{C}$ & E & $\mathrm{C}$ & $\mathrm{E}$ \\
\hline $\begin{array}{l}\text { Glucose } \\
(\mathrm{mmol} / \mathrm{L})\end{array}$ & $\begin{array}{c}3.26 \\
\pm 0.15\end{array}$ & $\begin{array}{c}7.45 \\
\pm 0.33^{*}\end{array}$ & $\begin{array}{c}4.53 \\
\pm 0.67\end{array}$ & $\begin{array}{c}23.11 \\
\pm 1.18^{*}\end{array}$ & $\begin{array}{c}4.72 \\
\pm 1.04\end{array}$ & $\begin{array}{l}26.17 \\
\pm 0.29 *\end{array}$ & $\begin{array}{c}4.88 \\
\pm 0.22\end{array}$ & $\begin{array}{c}27.63 \\
\pm 1.25 *\end{array}$ \\
\hline $\begin{array}{l}\text { Protein } \\
(\mathrm{g} / \mathrm{L})\end{array}$ & $\begin{array}{l}14.53 \\
\pm 0.36\end{array}$ & $\begin{array}{c}21.42 \\
\pm 0.55^{*}\end{array}$ & $\begin{array}{l}14.63 \\
\pm 0.27\end{array}$ & $\begin{array}{l}19.12 \\
\pm 0.34\end{array}$ & $\begin{array}{l}13.78 \\
\pm 0.58\end{array}$ & $\begin{array}{l}14.75 \\
\pm 1.06^{*}\end{array}$ & $\begin{array}{l}15.40 \\
\pm 1.61\end{array}$ & $\begin{array}{l}9.77 \\
\pm 0.56 *\end{array}$ \\
\hline $\begin{array}{l}\mathrm{LDH} \\
(\mathrm{IU} / \mathrm{L})\end{array}$ & $\begin{array}{c}3.45 \\
\pm 0.58\end{array}$ & $\begin{array}{c}7.46 \\
\pm 0.33^{*}\end{array}$ & $\begin{array}{c}4.03 \\
\pm 0.27\end{array}$ & $\begin{array}{c}7.07 \\
\pm 1.13^{*}\end{array}$ & $\begin{array}{l}3.92 \\
\pm 0.66\end{array}$ & $\begin{array}{c}6.88 \\
\pm 1.05^{*}\end{array}$ & $\begin{array}{c}4.14 \\
\pm 0.31\end{array}$ & $\begin{array}{c}7.14 \\
\pm 1.22 *\end{array}$ \\
\hline $\begin{array}{l}\text { AST } \\
(\mathrm{IU} / \mathrm{L})\end{array}$ & $\begin{array}{l}15.19 \\
\pm 0.45\end{array}$ & $\begin{array}{c}20.54 \\
\pm 1.18^{*}\end{array}$ & $\begin{array}{c}15.54 \\
\pm 1.15\end{array}$ & $\begin{array}{l}20.47 \\
\pm 0.83 *\end{array}$ & $\begin{array}{l}14.97 \\
\pm 0.36\end{array}$ & $\begin{array}{l}21.59 \\
\pm 0.95 *\end{array}$ & $\begin{array}{l}15.63 \\
\pm 0.28\end{array}$ & $\begin{array}{l}22.39 \\
\pm 1.18^{*}\end{array}$ \\
\hline $\begin{array}{l}\text { ALT } \\
(\mathrm{IU} / \mathrm{L})\end{array}$ & $\begin{array}{l}23.62 \\
\pm 1.19\end{array}$ & $\begin{array}{l}25.95 \\
\pm 0.35^{*}\end{array}$ & $\begin{array}{c}23.08 \\
\pm 1.32\end{array}$ & $\begin{array}{l}27.17 \\
\pm 1.05^{*}\end{array}$ & $\begin{array}{l}21.45 \\
\pm 0.28\end{array}$ & $\begin{array}{c}27.85 \\
\pm 1.37 *\end{array}$ & $\begin{array}{l}23.26 \pm \\
0.51\end{array}$ & $\begin{array}{l}28.53 \\
\pm 1.22 *\end{array}$ \\
\hline
\end{tabular}


Table 2: Variations in the ROS markers of $C$ mrigala exposed to barium chloride (1.2 ppm)

\begin{tabular}{|c|c|c|c|c|c|c|c|c|}
\hline \multirow{3}{*}{$\begin{array}{c}\text { ROS } \\
\text { variables }\end{array}$} & \multicolumn{8}{|c|}{ Exposure duration (in h) $1.2 \mathrm{ppm}$} \\
\hline & \multicolumn{2}{|c|}{24} & \multicolumn{2}{|c|}{48} & \multicolumn{2}{|c|}{72} & \multicolumn{2}{|c|}{96} \\
\hline & $\mathrm{C}$ & $\mathrm{E}$ & $\mathrm{C}$ & E & $\mathrm{C}$ & $\mathrm{E}$ & $\mathrm{C}$ & E \\
\hline $\begin{array}{l}\text { SOD } \\
\text { (U/mL protein) }\end{array}$ & $\begin{array}{c}5.32 \\
\pm 0.71\end{array}$ & $\begin{array}{l}3.94 * \\
\pm 0.19\end{array}$ & $\begin{array}{c}5.57 \\
\pm 0.07\end{array}$ & $\begin{array}{l}4.12 * \\
\pm 0.26\end{array}$ & $\begin{array}{r}4.98 \\
\pm 0.37\end{array}$ & $\begin{array}{l}4.02 * \\
\pm 022\end{array}$ & $\begin{array}{c}5.12 \\
\pm 0.44\end{array}$ & $\begin{array}{c}3.97 \\
\pm 0.34\end{array}$ \\
\hline $\begin{array}{l}\text { CAT } \\
(\mu \mathrm{mol} / \mathrm{ml} \\
\text { protein/min })\end{array}$ & $\begin{array}{c}2.54 \\
\pm 0.04\end{array}$ & $\begin{array}{c}1.96 \\
\pm 0.35^{*}\end{array}$ & $\begin{array}{c}2.99 \\
\pm 0.12\end{array}$ & $\begin{array}{c}2.01 \\
\pm 0.18 *\end{array}$ & $\begin{array}{c}2.43 \\
\pm 0.14\end{array}$ & $\begin{array}{l}1.68 \\
\pm 0.29 *\end{array}$ & $\begin{array}{r}2.27 \\
\pm 0.77\end{array}$ & $\begin{array}{l}1.84 \\
\pm 0.48 *\end{array}$ \\
\hline $\begin{array}{l}\mathrm{nmol} \text { of } \\
\mathrm{MDA} / \mathrm{mg} \\
\text { protein) }\end{array}$ & $\begin{array}{r}4.38 \\
\pm 0.54\end{array}$ & $\begin{array}{c}4.88 \\
\pm 0.63^{*}\end{array}$ & $\begin{array}{l}4.77 \\
\pm 0.66\end{array}$ & $\begin{array}{c}5.09 \\
\pm 0.44\end{array}$ & $\begin{array}{c}4.92 \\
\pm 0.15\end{array}$ & $\begin{array}{c}5.14 \\
\pm 0.92 *\end{array}$ & $\begin{array}{c}3.98 \\
\pm 0.21\end{array}$ & $\begin{array}{c}4.97 \\
\pm 0.56^{*}\end{array}$ \\
\hline
\end{tabular}

All values are expressed as mean \pm SE of three individual samples, ${ }^{*} P<0.05$ is significant.

Fig 1: Alterations in the brain glutamate level of C. mrigala exposed to $\mathrm{BaCl}_{2}$ (1.2 ppm) upon short term treatment

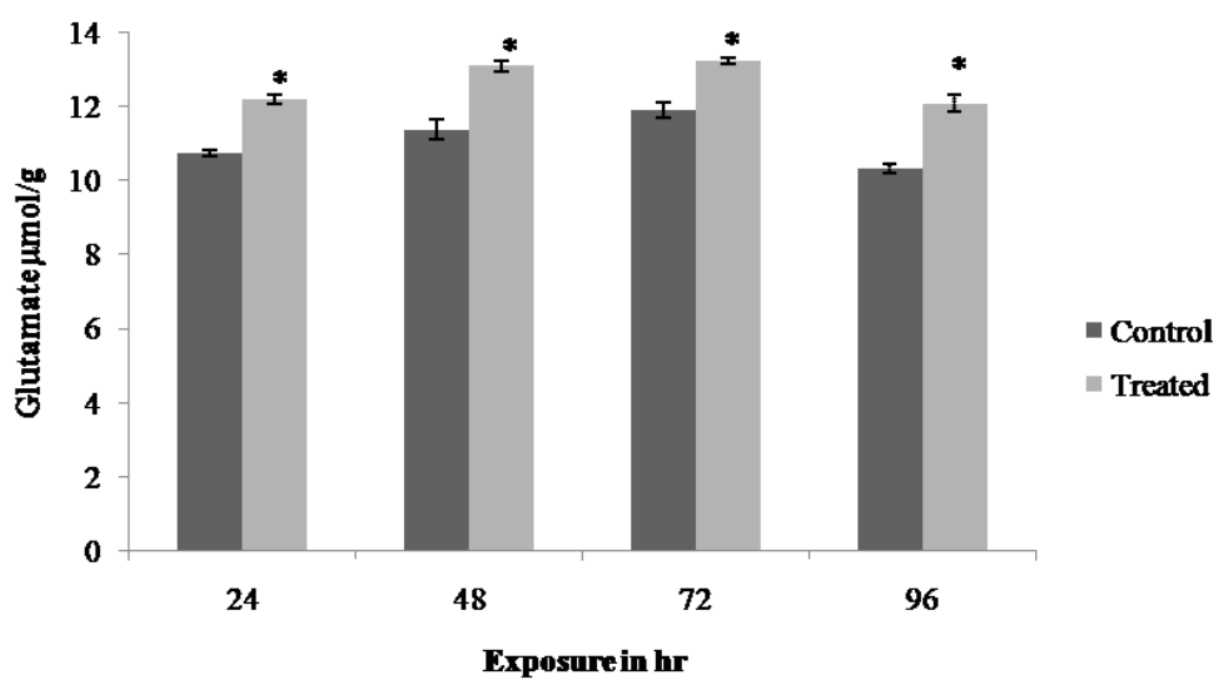

All values are expressed as mean $\pm \mathrm{SE}$ of three individual samples, ${ }^{*} P<0.05$ is significant

\section{DISCUSSION}

The physiological modifications during interaction of freshwater fish $\mathrm{C}$ mrigala and $1.2 \mathrm{ppm}$ of $\mathrm{BaCl}_{2}$ was recorded by studying different variables. There was a considerable rise in glucose levels in treated fish. The outcome can be credited to hyperglycemia due to stress. Comparable findings are reported, which are attributed to the changes in carbohydrate metabolism, owing to glycogenolysis in fish. Elevation in glucose upon metal exposure has been reported, because of glucose synthesis from amino acids of extra hepatic tissue (Almeida, 2001; Banaee et al., 2019). Other reports 
correlated raise in plasma glucose contents to the release of glucocorticoids and catecholamines from adrenal tissues of fish under toxic induced stress (Klaper, 2010). The protein levels progressively declined in the treated fish as period of exposure increased. The reduced protein content is associated with binding of metal to blood and tissue proteins, resulting in tissue damage and oxidative stress. This process changes the physicochemical characteristics which causes change in protein structure conformation (Chen et al., 2011), thus may be the basis of reduction in protein concentration in the present study. The toxicity by metals is the rationale behind declined protein levels as it inhibits transcription and translational processes.

The abnormal presence of transaminases; like aspartate transaminase (AST/GOT) and alanine transaminase (ALT/GPT) in the blood, is a sign of tissue damage. The detection of these biomarkers is usually related to inhibition of enzyme in metabolism due to exertion of stress. In the current study there was a notable elevation in both ALT/AST levels in treated fish. These findings are due to tissue and organ injury caused by contact to toxicants (Abhijith et al., 2016). These observations indicate the role of transaminases as major biomarkers during exposure to xenobiotics. AST and ALT are markers in liver function tests, as AST is synthesized by liver hepatocyte and typically found in liver and heart, while ALT, basically, is present in liver and kidney. Consequently, increased activity of these enzymes has been reported in fish exposed to xenobiotics (Rao, 2006). The raise in LDH can be ascribed to rapid glycolysis due to metabolic stress. Additionally, the onset of anoxia is also a cause for higher LDH activity. The anaerobic condition caused due to metal toxicity is reported to increase LDH activity (Min et al., 2008).

Figure (1) displays higher brain glutamate contents in treated fish compared to the control. This may be integrated with exotoxicity and undue generation of glutamate, and that may result in death and damage of nerve cells. The high glutamate levels changes the brain physicochemical environment, leading to the activation of the glutamate receptors that allows high concentration of calcium ions to permeate the cell (Manev et al., 1989). Generation of free radicals (ROS) is the reason for oxidative stress, thus disturbing the biological processes by upsetting homeostasis (Chandra et al., 2017). This causes imbalance in equilibrium of the detoxification mechanism of reactive oxygen species through antioxidants (Manke $\boldsymbol{e t}$ al., 2013). To scavenge the excessive generation of free radicals, cells adopt the mechanism of enzymatic and non-enzymatic responses (Chandra \& Sukumaran, 2020). Xenobiotics cause free radical generation during mitochondrial respiration and activate NADPH-like enzymes. In this study, superoxide dismutase and catalase activity decreased periodically with exposure to barium chloride. Enzymes; like superoxide dismutase (SOD) and catalase (CAT), play chief role in scavenging free radical produced during stress to the metabolic and physiological processes. Superoxide dismutase has been shown to be the immediate response to oxidative stress in biological system (Puneeth \& Chandra, 2020). This is because of the $\mathrm{O}_{2}$ generation and its conversion to $\mathrm{H}_{2} \mathrm{O}_{2}$, which leads to oxidation of cysteine in the antioxidant enzyme, thus confirming $\mathrm{BaCl}_{2}$ toxicity.

Lipid peroxidation (LPO) is the primary cause in the damage of cell structure and function, because of excessive production of free radicals (Huang et al., 2003). The lipid peroxidation mechanism is understood by measuring the malondialdehyde (MDA) levels, which is one of the end products of lipid breakdown due to peroxidation. The current 
result suggests that the existing cellular defense mechanism was not competent to avert the oxidative damage ( Chandra et al., 2020; Chandra \& Sukumaran, 2020; Jagadeep et al., 2020).

\section{REFERENCES}

Abhijith, B.D.; Ramesh, M. and Poopal, R.K.(2016). Responses of metabolic and antioxidant enzymatic activities in gill, liver and plasma of Catla catla during methyl parathion exposure, The Journal of Basic \& Applied Zoology 77: 31-40.

Affonso, E. G.; Polez, V. L. P.; Corrêa, C. F.; Mazon, A. F.; Araujo, M. R. R.; Moraes, G. and Rantin, F. T. (2002). Blood parameters and metabolites in the teleost fish Colossoma macropomum exposed to sulfide or hypoxia. Comparative Biochemistry and Physiology Part C: Toxicology \& Pharmacology, 133(3), 375-382.

Almeida, J. A.; Novelli, E. L. B.; Silva, M. D. P. and Júnior, R. A. (2001).Environmental cadmium exposure and metabolic responses of the Nile tilapia, Oreochromis niloticus. Environmental Pollution, 114(2): 169-175.

Ananda S,; Shaohua Z. and Liang L.; (2013). Fatal barium chloride poisoning: four cases report and literature review. The American Journal of Forensic Medicine and Pathology. 1:34(2):115-8.

Antisari, L. V.; Carbone, S.; Gatti, A.;Vianello, G. and Nannipieri, P. (2013). Toxicity of metal oxide $\left(\mathrm{CeO}_{2}, \mathrm{Fe}_{3} \mathrm{O}_{4}, \mathrm{SnO}_{2}\right)$ engineered nanoparticles on soil microbial biomass and their distribution in soil. Soil biology and biochemistry, 60: 87-94.

Banaee, M.; Sureda, A.; Taheri, S. and Hedayatzadeh, F. (2019). Sub-lethal effects of dimethoate alone and in combination with cadmium on biochemical parameters in freshwater snail, Galba truncatula. Comparative Biochemistry and Physiology Part C: Toxicology \& Pharmacology, 220: 62-70.

Buege, J.A. and Aust S. D. (1978) Microsomal lipid peroxidation. Methods in Enzymology,31; 52: 302-10.

Chandra, S. P.; Puneeth, H. R.; Mahadimane, P. V. and Sharada, A. C. (2017). Biochemical Evaluation of Cordia dichotoma Seed Extracts. Advanced Science Letters, 23(3):1823-1825.

Chandra, S. and Sukumaran, S. (2020).Physiological, Biochemical and Neurochemical responses of Cirrhinus mrigala upon short term exposure to Cerium oxide. International Journal of Aquatic Biology, 7(6):368-373.

Chandra, S.J,; Kote, N.V.; Sandya, S. and Sharath Chandra, S.P. (2020). Lithium Nitrate Induced Biochemical Modifications in catla catla upon Short Term Exposure. Pharmacognosy journal.;12(6)Suppl:1705-9.

Chen, P. J.; Su, C. H.; Tseng, C. Y.; Tan, S. W. and Cheng, C. H. (2011). Toxicity assessments of nanoscale zerovalent iron and its oxidation products in medaka (Oryzias latipes) fish.Marine pollution bulletin, 63(5-12): 339-346.

Cooper GR. and McDaniel (1970) Standard methods of clinical chemistry. Academic, New York, 159.

Das, K.; Samanta, L. and Chainy, G.B.N. (2000) A modified spectrophotometric assay of superoxide dismutase using nitrite formation by superoxide radicals. Indian Journal of Biochemistry and Biophysics 37: 201-204. 
Drabkin, D.L. (1946) Spectrophotometric studies XIV. The crystallographic and optical properties of the hemoglobin of man in comparison with those of other species. Journal of Biological Chemistry 1;164(2):703-23.

Foyer, C. H. and Noctor, G. (2005). Oxidant and antioxidant signalling in plants: a reevaluation of the concept of oxidative stress in a physiological context. Plant, Cell \& Environment, 28(8): 1056-1071.

Gambardella, CH. T.; T. Mesaric, K.; Milivojevic, L.; Sepcic, S.; Gallus, S.; Carbone, Ferrando. and M. Faimali. (2014) Effects of selected metal oxide nanoparticles on Artemia salina larvae: evaluation of mortality and behavioral and biochemical responses. Environmental Monitoring and assessment: 4249- 4259.

Goth L. (1991) A simple method for determination of serum catalase activity and revision of reference range. ClinChimActa 15;196(2-3):143-51.

Heinlaan, M.; Blinova, I.; Dubourguier, H.C. and Kahru, A. (2008) Toxicity of nanosized and bulk $\mathrm{ZnO}, \mathrm{CuO}$ and $\mathrm{TiO} 2$ to bacteria Vibrio fischeri and crustaceans Daphnia magna and Thamnocephalus platyurus. Chemosphere 71:1308-1316.

Jagadeep, C.S.; Chandana, G.L.; Kote, N.V. and Sharath Chandra, S. P. (2020). Recent Scenario of Impact of Xenobiotics on Marine Fish: An Overview. Pharmacognosy Journal, 12(6)Suppl,:1797-800.

Jin, W. X.; Ma, S. Y.; Tie, Z. Z.; Li, W. Q.; Luo, J.; Cheng, L. and Mao, Y. Z. (2015).Synthesis of hierarchical SnO2 nanoflowers with enhanced acetic acid gas sensing properties.Applied Surface Science, 353: 71-78.

Klaper, R.; Arndt, D.; Setyowati, K.; Chen, J. and Goetz, F. (2010). Functionalization impacts the effects of carbon nanotubes on the immune system of rainbow trout, Oncorhynchus mykiss. Aquatic toxicology, 100(2): 211-217.

Li, K. N.; Wang, Y. F.; Xu, Y. F.; Chen, H. Y.; Su, C. Y. and Kuang, D. B. (2013). Macroporous $\mathrm{SnO} 2$ synthesized via a template-assisted reflux process for efficient dye-sensitized solar cells. ACS applied materials \& interfaces, 5(11): 5105-5111.

Lowry, OH.; Rosebrough, NJ.; Farr, AL. and Randall, RJ. (1951) Protein measurement with the Folin phenol reagent. Journal of Biological Chemistry 1;193(1):265-75.

Luo, JJ.; Hsieh, LL. and Chang, MJW. (2002). Decreased white blood cell counts in semiconductor manufacturing workers in Taiwan. Occupational and Environmental Medicine, 59:44-48.

Manke, A.; Wang, L. and Rojanasakul, Y. (2013) Mechanisms of nanoparticle-induced oxidative stress and toxicity. BioMedical Research International: 916-942.

McCauley PT. and Washington IS. (1983) Barium bioavailability as the chloride, sulfate, or carbonate salt in the rat. Drug and chemical toxicology. 1, 6(2):209-17.

Min, E. Y. and Kang, J. C. (2008).Effect of waterborne benomyl on the hematological and antioxidant parameters of the Nile tilapia, Oreochromis niloticus. Pesticide Biochemistry and Physiology, 92(3): 138-143.

Nelson, DA. and Morris, MW. (1989) Basic methodology. Hematology and coagulation, part IV. Clinical diagnosis and management by laboratory methods, 7 th edn. Saunder Company, Philadelphia: 578-724.

Perva, S.;Swamy, K.; Chandrashekar, N.; Subramanian, R.; Sukumaran, S. and Chandra SP, S. (2020). Physio-biochemical responses of Indian major carp Catla catla 
upon sub-chronic exposure to tin oxide nanoparticles. Egyptian Journal of Aquatic Biology and Fisheries, 24(4): 509-520.

Puneeth, H. R. and Chandra, S. S. P. (2020).A review on potential therapeutic properties of Pomegranate (Punica granatum L.). Plant Science Today, 7(1): 9-16.

Raddam, Q. N.; Zeidan, M. M.; Asaad, N. K. and Abdulrahman, M. A. (2017). Smoking effects on blood antioxidants level: lactate dehydrogenase, catalase, superoxide dismutase and glutathione peroxidase in university students. Journal of Clinical \& Experimental Pathology, 7(6): 2161-0681.

Raju, TR.; Kutty, BM.; Sathyaprabha, TN. and Shankarnarayana, Rao BS. (2004). Brain and behavior.National Institute of Mental Health and neurosciences, Bangalore.pp.134-138.

Ranjitha, T. and Sharath Chandra SP. (2020) Biological and ecological impact of iron and iron nanoparticles across diverse array of fish models: a review. Ecology, Environment and Conservation, 26 (1): 180-184

Rao, J. V. (2006). Sublethal effects of an organophosphorus insecticide (RPR-II) on biochemical parameters of tilapia, Oreochromis mossambicus. Comparative Biochemistry and Physiology Part C: Toxicology \& Pharmacology, 143(4): 492-498.

Rashmi, N.; Ranjitha, T. and Sharath Chandra, SP. (2019). Chromium and their derivatives causes physiological and biochemical modifications in diverse fish models: A Review. Biomed Pharmacol J 12 (4): 2049-2053.

Roopan, S.M.; Kumar, S.H.S.; Madhumitha, G. and Suthindhira, K. (2014) Biogenic-production of $\mathrm{SnO}_{2}$ nanoparticles and its cytotoxic effect against hepatocellular carcinoma cell line $\left(\mathrm{HepG}_{2}\right)$. Appl. Biochem. Biotechnol: 1381-5.

Rusia, V. and Sood, SK. (1992) Routine hematological tests. In: Mukerjee KL (ed) Medical laboratory technology. Tata McGraw Hill Publishing Company Limited, New Delhi: 252-258.

Shah, S. L. and Altindag, A. (2004).Hematological parameters of tench (Tincatinca L.) after acute and chronic exposure to lethal and sublethal mercury treatments.Bulletin of environmental contamination and toxicology, 73(5): 911-918.

Shaluei, F.; Hedayati, A.; Jahanbakhshi, A.; Kolangi, H. and Fotovat, M. (2013) Effect of subacute exposure to silver nanoparticle on some hematological and plasma biochemical indices in silver carp (Hypophthalmichthys molitrix). Human \& Experimental Toxicology 32(12): 1270-1277.

Sharath Chandra, S. P. and Sukumaran, S. (2020). Magnesium chloride impairs physio- biochemical and neurochemical responses in cirrhinus mrigala (Hamilton, 1822) upon short term exposure. Biointerface Research in Applied Chemistry, 10(1),: 4934-4938.

Winston, G. W. and Di Giulio, R. T. (1991).Prooxidant and antioxidant mechanisms in aquatic organisms.Aquatic toxicology, 19(2):137-161. 